\title{
Dispersal of wood mice and bank voles in an agricultural landscape
}

\author{
Zhibin ZHANG $^{1}$ and Michael B. USHER ${ }^{2}$
}

\begin{abstract}
Zhang Z. and Usher M. B. 1991. Dispersal of wood mice and bank voles in an agricultural landscape. Acta theriol. 36: $239-245$.

The aim of the study reported in this paper was to investigate the dispersal of wood mice (Apodemus sylvaticus) and bank voles (Clethrionomys glareolus) between small woodlands in an agricultural landscape. By using live trapping and capture-mark-recapture methods, 1017 wood mice and bank voles were trapped and 78 movements between habitats were monitored. The results demonstrate that hedgerows are important both for settlement and for corridors for dispersing small mammals. The study also tends to indicate that increasing distance and lack of hedgerows reduces the number of wood mice moving between woodlands, and that the degree of isolation may vary in time depending on the nature of the ground cover provided by the arable crop.

Department of Biology, University of York, York Y01 5DD, United Kingdom

Key words: Apodemus sylvaticus, Clethrionomys glareolus, dispersal, agricultural landscape
\end{abstract}

\section{Introduction}

In the mosaic of habitat fragments in agricultural landscapes, dispersal is vital for wildlife survival. Without dispersal, the local populations would face genetic problems, e.g. inbreeding, loss of heterozygosity, etc. (see Usher 1987) and hence a larger probability of local extinction would be expected. With wildlife habitats in farmland being fragmented, and often isolated, it becomes important to understand the dispersal of species between these fragments and the use of intervening habitats by those species.

Woodlands are typical habitat fragments for the small mammals of agricultural landscapes. Roads, cropland, grassland and drainage ditches have all been found to be barriers for dispersal of small mammals, such as chipmunks (Tamias striatus), wood mice (Apodemus sylvaticus), white-footed mice (Peromyscus leucopus), house mice (Mus musculus) and bank voles (Clethrionomys glareolus) (Oxley et al. 1974, Mader 1984, Henderson et al. 1985, Bakowski and Kozakiewicz 1988). Hedgerows, narrow strips of woody vegetation (rarely exceeding either $2 \mathrm{~m}$ in width or height), form barriers between fields and may be seen as connecting isolated woodlands. Their roles both as habitats and as corridors in facilitating the movements of small mammals have been reported (e.g. Wegner and Merriam 1979, Henderson et al. 1985, Corenz and Barrett 1990), but there are still questions about the extent of woodland isolation,

Present address: 'Department of Animal Ecology, Institute of Zoology, Academia Sinica, Beijing 100080, People's Republic of China; ${ }^{2}$ Nature Conservancy Council for Scotland, Research and Development Division, 2/5 Anderson Place, Edinburgh EH6 5NP, United Kingdom 
and whether the hedgerows are actually essential for dispersal of small mammals in agricultural landscapes.

This paper has two aims. The first is to study the effects of distance between farm woodlands and hedgerow connection on the dispersal of wood mice Apodemus sylvaticus (Linnaeus, 1758) and bank voles Clethrionomys glareolus (Schreber, 1780) between woods. The second is to assess the role of hedgerows as habitats and as corridors for wood mice and bank voles.

\section{Study area, methods and materials}

The study was carried out in an agricultural area in the parish of Escrick, about $10 \mathrm{~km}$ south of York, England (approx. $53^{\circ} 53^{\prime} \mathrm{N}, 1^{\circ} 01^{\prime} \mathrm{W}$ ). The area was selected because of the mosaic of arable fields, hedges, small woodlands, tracks and roads, and farm buildings.

The sampling design consisted of trapping in three woods, two arable fields and four hedgerows (see Fig. 1). The isolation characteristics of the three woods are listed in Table 1. The number of traps, and the

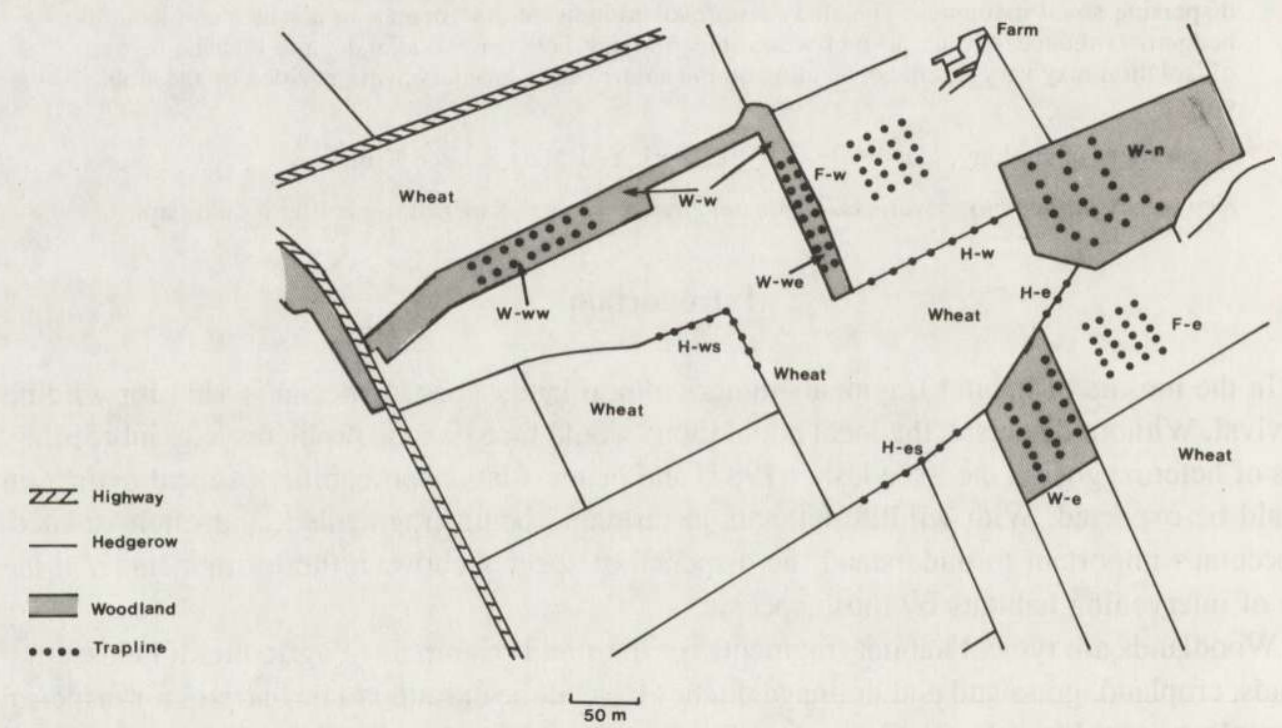

Fig. 1. The study area and its surroundings. The woodlands and hedgerows studied are indicated by symbols. The traplines are also shown by rows (in hedges) or grids (in woods and fields) of dots. W-ww and W-we are two traplines in wood W-w.

spacing between them, varied between the locations. Ten traps were placed in each of the hedges, except for hedge $\mathrm{H}-\mathrm{w}$ in which 15 traps were placed. The traps were in a transect along the hedge and were $15 \mathrm{~m}$ apart, except in hedge $\mathrm{H}$-e when the spacing had to be reduced to $10 \mathrm{~m}$. In both of the fields 20 traps were placed on a square grid of 4 rows of 5 traps, with $15 \mathrm{~m}$ spacing between rows and between traps within rows. Forty traps were used in both of the woods W-e and W-w on grids with 10 traps per row and $15 \mathrm{~m}$ separation between traps and rows. In wood W-n the grid for 50 traps was of 3 rows of 16 or 17 traps, again with a spacing of $15 \mathrm{~m}$ between rows and between traps within rows.

Intensive live trapping was carried out between August and October 1990. Four trapping periods, each of 10 days with intervals of about 10 days between them, were used. The Longworth traps were provided with 
bedding material and baited with a mixture of Dipteran pupae and pet food (sold for hamsters). All animals that were captured were marked by toe-clipping, and information about each was recorded (i.e. species, habitat, grid position, date, weight, sex and breeding conditions, as well as the weather). The animal was then released in the same place as it was captured.

The percentage dispersal rate, $D$, between two habitats, $x$ and $y$, was calculated by the equation

$$
D=100\left(X_{2}+Y_{2}\right) /\left(X_{4}+Y_{4}\right)
$$

If $X_{1}$ mammals, marked in habitat $x$, were re-trapped in habitat $x, X_{2}$ were re-trapped in habitat $y$, and $X_{3}$ in all other habitats, the dispersal rate from habitat $x$ to habitat $y$ is $X_{2} / X_{4}$, where $X_{4}=X_{1}+X_{2}+X_{3}$, with similar expressions for the $Y_{1}$ mammals marked and recaptured in habitat $y, Y_{2}$ recaptured in habitat $x$ and $Y_{3}$ recaptured in all other habitats.

Table 1. Isolation characteristics of the three woodlands, shown as W-n, W-e and W-w in Fig. 1.

\begin{tabular}{lcll}
\hline Woods compared & $\begin{array}{c}\text { Distance of } \\
\text { separation }(\mathrm{m})\end{array}$ & $\begin{array}{c}\text { Hedgerow } \\
\text { connection }\end{array}$ & Isolation \\
\hline W-n \& W-e & 106 & Yes (by H-e) & Little \\
W-n \& W-w & 264 & Yes (by H-w) & Larger \\
W-w \& W-e & 278 & $\begin{array}{l}\text { No (except } \\
\text { through W-n) }\end{array}$ & Largest \\
& & & \\
\hline
\end{tabular}

Table 2. Numbers of small mammals trapped in the woods, hedgerows and fields shown in Fig. 1.

\begin{tabular}{lrrrrrrrrrr}
\hline \multirow{2}{*}{ Species } & \multicolumn{1}{c}{ Habitats } & & & \\
& W- $\mathrm{n}$ & W-e & W-w & H-e & H-w & H-ws & H-es & F-w & F-e & Total \\
\hline Total no of trap days & 1000 & 800 & 800 & 400 & 300 & 150 & 150 & 100 & 100 & 3800 \\
Apodemus & 296 & 197 & 179 & 46 & 70 & 42 & 46 & 12 & 3 & 891 \\
Clethrionomys & 23 & 46 & 18 & 18 & 14 & 5 & 2 & 0 & 0 & 126 \\
S. araneus & 5 & 1 & 1 & 0 & 0 & 0 & 0 & 0 & 0 & 7 \\
S. minutus & 12 & 0 & 1 & 3 & 7 & 1 & 0 & 0 & 0 & 24 \\
Total & 336 & 244 & 199 & 67 & 91 & 48 & 48 & 12 & 3 & 1048 \\
Density (\%) & 34 & 31 & 25 & 17 & 30 & 32 & 32 & 12 & 3 & 28 \\
\hline
\end{tabular}

\section{Results}

\section{Numbers of animals}

From 11 August to 16 October 1990, a total of 1048 animals was trapped. A. sylvaticus made up $85 \%$ of the catch, C. glareolus $12 \%$, and shrews Sorex spp. $3 \%$ (see Table 2). The average density (numbers of small mammals per 100 trap nights) was $30 \%$ in woods, not significantly larger than the density of $25 \%$ in hedgerows ( $t=0.73$ with 5 d.f.). The density of Apodemus was $26 \%$ in woods, again not significantly larger than the density of $20 \%$ in hedgerows ( $t=0.45$ with 5 d.f.). The density of Clethrionomys was $3.4 \%$ in woods, similar 
to the density of $3.8 \%$ in hedgerows. The density of Apodemus in the crop fields was much lower than that in either woods or hedgerows. The peak month for Apodemus was in September when 353 were trapped over the 10 day period, whilst, for Clethrionomys it was in August when 58 were trapped. It should be noted that the average density was greatest in September because of the abundance of Apodemus, when it was approximately $40 \%$.

\section{Dispersal and movements}

A total of 78 movements ( 66 of Apodemus, 12 of Clethrionomys and none of Sorex) was found between woods, between woods and hedgerows or between woods and fields. Therefore only dispersal of Apodemus is analysed here.

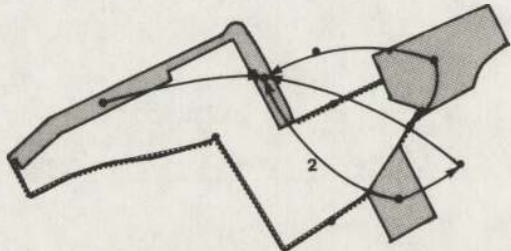

August $11-20$

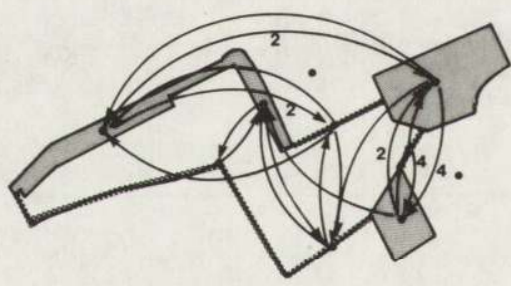

September $18-27$

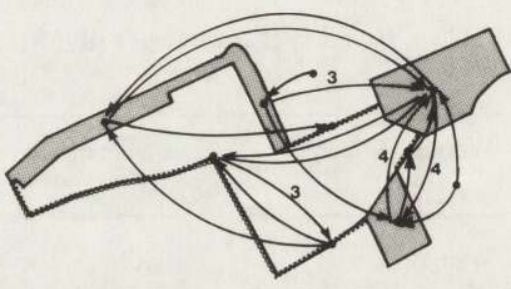

August 30 - September 8

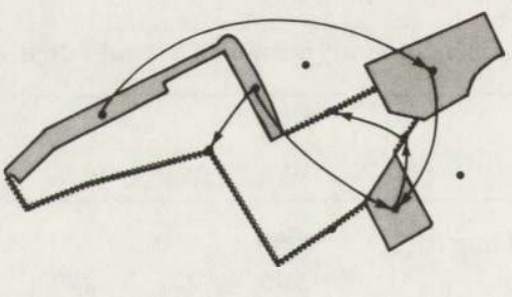

October 7-16

Fig. 2. Maps of the movements of Apodemus between habitat features. The movements are indicated diagrammatically between the centres of the habitats, in the direction of the arrows. The numbers for only one movement are omitted; where there were two or more movements these are shown by appropriate numbers.

Fig. 2 shows the movements of Apodemus between habitats in each of the four trapping periods. These maps tend to indicate that these small mammals used the hedgerows as corridors for moving between woods, although there is also evidence that wood mice cross open fields for short distances. Of the 66 observed movements, 46 of them were between woods and adjoining hedgerows, or between woods connected by hedgerows. 14 of the movements were over larger distances in terms of hedgerow connections, and 6 were between fields and woods, suggesting that wood mice will cross the arable fields. However, during the first and fourth trapping periods there was a larger percentage of animals ( 5 of the 13 observed movements) apparently crossing fields than during the other two periods ( 9 of the 53 observed movements). The reasons for these apparent differences are obscure. It may be because of the intensive 
agricultural activity, sowing winter wheat, during the second and third trapping periods. Alternatively, it may be related to ground cover, since during the first period there was wheat stubble standing in the fields and during the last period the new wheat crop had germinated.

In order to investigate the effects of distance and hedgerow connectivity on dispersal, the dispersal rates between the three woods (Table 1) were calculated. Because no movements of Clethrionomys were observed between the woods, only dispersal of Apodemus is considered here, and because of the relatively small sample size all of the data for the four trapping periods have been pooled. Between wood W-n and W-e, the dispersal rate $D$ was $4.8 \%$, whereas between W-n and W-w $D=3.5 \%$; there are hedgerows between both these pairs of woods, but the distance between the former pair of woods is shorter than between the latter pair of woods. Between W-w and W-e, $D=2.2 \%$; it is notable that the distance between this pair of woods is very similar to that between $\mathrm{W}-\mathrm{n}$ and $\mathrm{W}-\mathrm{w}$, but there is no continuous hedgerow connection.

Table 3. The number of days that small mammals are known to be resident in woods or hedgerows after they have been captured, marked and released, as well as the percentages remaining in the habitats in which they were released. $\mathrm{n}$ - indicated sample size, and ns implies non-significant values of the test statistics.

\begin{tabular}{lccc}
\hline Statistic & Hedgerows & Woods & Test \\
\hline Apodemus & & & \\
Mean no. of days & 13.7 & 14.8 & $t=0.48 \mathrm{~ns}$ \\
Standard deviation & 11.4 & 12.8 & \\
n & 38 & 131 & \\
Percentage remaining & 57 & 58 & $z=0.25 \mathrm{~ns}$ \\
n & 198 & 643 & \\
Clethrionomys & & & \\
Mean no. of days & 9.4 & 13.3 & $t=0.78 \mathrm{~ns}$ \\
Standard deviation & 8.1 & 13.2 & \\
n & 8 & 21 & \multirow{2}{*}{. } \\
Percentage remaining & 47 & 60 & \\
n & 34 & 77 & $\mathrm{~ns}$ \\
\hline
\end{tabular}

These dispersal rates cannot be compared statistically because of the comparatively small sample sizes and the inability to replicate distances between pairs of woods or isolation of woods. However, the decreasing dispersal rates with increasing isolation tends to indicate that there is likely to be greater exchange of individuals between woods that are close and between woods that have hedgerow connections. The dispersal rates tend to hide the numbers of individuals exchanged between the woods. Between the nearest pair, W-n and W-e, 15 wood mice were trapped in the other wood to the one in which they were marked. With the greater separation between W-n and W-w the number of marked mice exchanged between the woods was 10 , whilst for the most isolated pair of woods (W-e and W-w) only 5 wood mice were known to have been exchanged. 
Hedgerows: are they good habitats for wood mice and bank voles?

If a hedgerow was a suitable habitat for wood mice and bank voles, it would not only facilitate long distance movements of animals as if it were a corridor, but it would also contain a resident population of each species. Two criteria can be used to test such a hypothesis. The first is the number of days an individual is known to be resident in a habitat after it has been captured, marked and released. The second is the percentage of individuals known to be remaining in the habitat after they have been captured, marked and released. If hedgerows are as good as woods for animals to live in, then there would be no difference between the two indices. Table 3 shows that there are no significant differences for either wood mice or bank voles between the hedgerows or the woods. The results of both tests therefore support the hypothesis that hedgerows are as good a habitat for wood mice and bank voles as woodlands.

\section{Discussion}

Isolation in agricultural environments has been implicated in the species richness of habitat fragments (e.g. Saunders et al. 1987). The habitat fragments themselves have been seen as refugia for small mammals, especially during winter (Ylönen et al. 1991). However, there are few studies that have focused on the ability of species to disperse between habitat fragments in the agricultural landscape.

This study was short-term (because of the sporting use of the farmland) and hance can only give an indication of the movement of small mammals within an agricultural landscape. However, a number of suggestions can be made. First, distance between woodlands and the presence or absence of hedgerow connections may affect dispersal of both wood mice and bank voles between the woodlands. If the wood is nearer to another wood, and has a hedgerow connection, more movements of wood mice were observed between the two woods. Genetic isolation may therefore only be important for a population of these small mammals living in an extremely isolated woodland without hedgerow connections to any other woodland. Second, there is the suggestion that the degree of isolation of woodlands in agricultural landscapes can vary with time. It is possible that if the arable land has good ground cover, wood mice and bank voles can cross more freely than when the fields are bare, but frequent disturbance due to agricultural activity can also limit small mammal movements. Third, hedgerows are good habitats for small mammals as well as being good corridors for dispersal between woods or between surrounding environmental features.

These results, indicating the role of hedgerows as corridors and habitats in facilitating the movements of wood mice and bank voles, are similar to those of Wegner and Merriam (1979) and Henderson et al. (1986). However, is woodland isolation varying in time depending upon the ground cover of the surrounding crop species, and will different crops facilitate small mammal movements away from woodlands to different extents? If there is variation of this sort, the presence of ground cover may be very important for the dispersal of small mammals. Further work needs to be undertaken so as to understand whether small mammals are able to perceive the surrounding environments when they are dispersing. 
In applying the concepts of island biogeography theory (MacArthur and Wilson 1967) to these woodland "islands", the hedgerow connections should be taken into account. From these studies, it appears that less isolation can be expected between woodlands in landscapes with many hedgerow connections than between woodlands in landscapes with few such connections. Whilst the hedgerows may facilitate movements between woodlands, they do themselves provide a reservoir of animals for dispersal around the landscape. Conservation of hedgerows, as well as the fragments of natural vegetation in the agricultural landscape, thus appears to be important for the conservation of small mammal biodiversity in the countryside.

Acknowledgements: Z. Z. would like to thank the Royal Society for the award of the Royal Fellowship that funded his travel to the United Kingdom and Dr. G. R. Singleton for his helpful comments on earlier drafts of this manuscript. We should both like to thank the owners, tenants and keepers of Escrick Estate for permission to work on their land and for their cooperation throughout this study.

\section{References}

Bakowski C. and Kozakiewicz M. 1988. The effect of forest roads on bank vole and yellow-necked mouse populations. Acta theriol. 33: $345-353$.

Corenz G. C. and Barrett G. W. 1990. Influence of simulated landscape corridors on house mouse (M. musculus) dispersal. Am. Midl. Nat. 123: 348 - 356.

Henderson M. T., Merriam G. and Wegner J. 1985. Patchy environments and species survival: Chipmunks in an agricultural mosaic. Biol. Conserv. 31: 95 - 105.

MacArthur R. H. and Wilson E. O. 1967. The theory of island biogeography. Princeton University Press, Princeton, N. J.: 1 - 203.

Mader H. J. 1984. Animal habitat isolation by roads and agricultural fields. Biol. Conserv. 29: 81 - 96.

Oxley D. J., Fenton M. B. and Carmody G. R. 1974. The effects of roads on populations of small mammals. J. appl. Ecol. 11: $51-59$.

Saunders D. A., Arnold G. W., Burbidge A. A. and Hopkins A. J. M. (eds). 1987. Nature conservation: the role of remnants of native vegetation. Surrey Beatty, Chipping Norton, New South Wales, Australia.

Usher M. B. 1987. Effects of fragmentation on communities and populations: a review with applications to wildlife conservation. [In: Nature conservation: the role of remnants of native vegetation. D. A. Saunders, G. W. Arnold, A. A. Burbidge and A. J. M. Hopkins, eds]. Surrey Beatty, Chipping Norton, New South Wales, Australia: $103-121$.

Wegner J. F. and Merriam G. 1979. Movements by birds and small mammals between a wood and adjoining farmland habitats. J. Appl. Ecol. 16: $349-357$.

Ylönen H., Altner H.-J. and Stubbe M. 1991. Seasonal dynamics of small mammals in an isolated woodlot and its dynamics of small mammals in an isolated woodlot and its agricultural surroundings. Ann. Zool. Fennici 28: 7 - 14 .

Received 11 March 1991, accepted 15 December 1991. 